Syntax Literate: Jurnal Ilmiah Indonesia p-ISSN: 2541-0849

e-ISSN: 2548-1398

Vol. 5, No. 8, Agustus 2020

\title{
DOMINANCE OF MARKET SHARE OF SUKUK IN INDONESIA
}

\author{
Dini Selasi \\ Ma'had Ali Islamic College of Religion Cirebon (STAIMA) Cirebon, Indonesia \\ Email: diniselasi1980@gmail.com
}

\begin{abstract}
Indonesia is one of the issuers of sukuk in the world with various series that have been issued, this sukuk aims to help finance the state budget for various sectors for sustainable development programs. This study uses a qualitative research method using a phenomenological approach. The results show that the government is still dominated by sukuk because most of the financing of sukuk in Indonesia are government projects in various sectors, in their issuance in collaboration with conventional and sharia banking, securities companies that become $\mathrm{AB}$ Bursa. Sukuk series issued by the government such as Islamic Fixed Rate (IFR), greensukuk, Indonesian hajj fund sukuk (SDHI), savings sukuk, retail sukuk, sharia state treasury bills (SPNS), project based sukuk (PBS).
\end{abstract}

Keywords: sukuk, market share, dominance

\section{Introduction}

In Islam, this endeavor is obligatory because it is an effort to make our lives better in all fields, including investment. Investment as a form of our efforts as humans to make economic life better because the assets we have must have zakat so that our assets are not consumed by zakat as in the letter At Taubah: 103 "Take zakat from some of their assets, with that zakat you clean. and sanctify them " (Ministry of Religion of the Republic of Indonesia, 2015). Investment is a form of implementing the use of assets for productive activities, the more productive, the greater the zakat, but the wheels of the economy will be better (Hidayat, 2011). In simple terms, zakat can still be paid as a cleansing of our assets which can be taken from the investment profits we get.

In Islam, all aspects of life are regulated in the Qur'an and Hadith, including investments in accordance with the sharia. There are several things that are not allowed in investment activities, namely maisir, gharar, usury, batil, bay'i ma'dium, ihtikar, taghrir, ghabn, talaqqi al-rukban, ghishsh, tanajush / najsh, dharar, rishwah, immorality and zalim (DSN-MUI., 2019). In addition, investment must be professional, starting from the type of business, the person or entity that manages it so that the investment can provide benefits for both (Putra, 2018). There are many types of investment that can be channeled for the development of our assets, many types of investment in the Islamic capital market, namely Islamic stocks, sukuk, Islamic mutual funds, Islamic exchange traded funds (ETF), sharia asset-backed securities (EBA), sharia real estate investment funds (DIRE) (IDX Islamic, n.d.). 
Sukuk investment in Indonesia is starting to be of interest to the public at large because it does not require large capital, the same as other types of investment in the Islamic capital market, sukuk is a type of securitization of assets in accordance with Islamic principles in the Islamic capital market (IDX Islamic, n.d.). Indonesia is a large country with a very large population so that Indonesia is a very potential market for various types of world investment, many world investors are interested in investing their capital.

Sukuk are starting to be of interest to the public in Indonesia with a very encouraging development, there are many sharia effects that can be used as an alternative investment in the Islamic capital market and sukuk are an alternative investment in Indonesia. However, the existence of sukuk is still dominated by the Government in its issuance in accordance with Law number 19 of 2008 concerning sukuk (Bank Indonesia, 2018) which is intended for government-owned infrastructure where the sukuk is a development financing that involves community participation.

In this study we will focus on the sukuk or state sharia-based letter (SBSN) in Indonesia, This research focuses on the development of sukuk issued by the Indonesian government and the extent of the government's dominance in issuing these sukuk and how the impact is generated by the issuance of government sukuk, the implementation of sukuk financing for infrastructure development in Indonesia and the development of the sukuk itself for development in Indonesia. If in the previous research only explained some types of sukuk, for example only savings sukuk or retail sukuk, but in this study it explains all types of sukuk issued by the government both to domestic investors and investors abroad with various types of sukuk, so it can be seen how the government dominates in issuing sukuk.

\section{Method}

This study uses a qualitative research method with a phenomenological approach, which significant statements, structural and textual descriptions, data sources are carried out by interviews, using documents, observation and art by trying to explain rationally, using assumptions and supporting data related to it . with this research (Creswell \& Clark, 2017). This study uses a qualitative research method with a phenomenological approach, data sources used are data from various agencies such as the roadmap for the Indonesian Islamic capital market, the internet, books on the Islamic capital market, especially about sukuk in general, statistical data so that it describes important statements and is able to describe. the development that occurred was the development of sukuk in Indonesia. Interviews in this study use a virtual system such as in the Islamic capital market webinars such as the head of the Islamic capital market division, members of the national sharia board (DSN). Observations were made by looking at the number and types of sukuk in Indonesia that were getting better, especially among stock investors who were starting to be interested in increasing their investment in sukuk through several groups on social media such as WhatsApp, Instagram, Telegram and others. 


\section{Results And Discussion}

Government policy to develop the Islamic financial market in Indonesia, the Government seeks to launch a sharia-based investment and financing instrument, namely State Sharia Securities (SBSN) or known as State Sukuk. The SBSN Law is a breath of fresh air for both the Government and market players in their efforts to develop domestic financial markets. So far, sukuk has developed conducive to economic development and stimulates investment development and has a positive effect on economic growth (Smaoui \& Khawaja, 2017).

The community is already familiar with investment activities, especially investments in the Islamic capital market, sukuk is one of the investment alternatives where Indonesia is not the first country to issue sukuk but Malaysia, which was issued in 2019 in the form of corporate sukuk, while the country's first issuing sukuk is country. Bahrain in 2001, meanwhile in Indonesia, the first to publish was PT. Indosat Tbk in the form of corporate sukuk in 2002 (Aminy, 2018).

The issuance of Indonesian sukuk is not only intended for the domestic market but for the international market as well as in 2009 the government issued Indonesian State Sukuk (SNI) or also known as Indonesian global sukuk, when the SNI 25 series sukuk in 2015 was issued sukuk on the international market this shows that the sukuk can be accepted by the international community, here is the distribution (Hariyanto, 2015).

Table 3. Distribution of Sukuk with International Investors

\begin{tabular}{ll}
\hline Spread of Investor Countries & Number (\%) \\
\hline the middle East & $41 \%$ \\
Europe & $16 \%$ \\
United States of America & $21 \%$ \\
Asia & $12 \%$ \\
Indonesia & $10 \%$ \\
\hline
\end{tabular}

Source: (Hariyanto, 2015)

The journey of issuing sukuk in Indonesia is not the first time in the world, but since its inaugural issuance to date it has in extraordinary developments, here is the journey of state sukuk from 2008 to 2016 (Finance., n.d.)starting from the issuance of Law No. 19 year 2008 concerning State Sharia Securities or SBSN.

Figure 1. State Sukuk Milestone 2008-2016 


\section{Milestone Sukuk Negara}

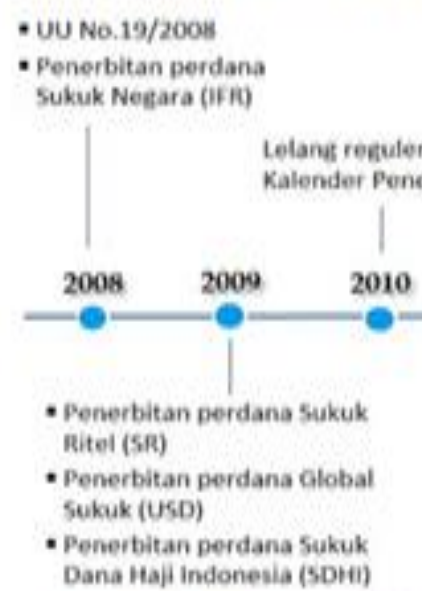

- Letans reguler SPN-5 a Pas (Project - based Sukuk)

- Penerbitan perdana Islamic Global MIN Proguram

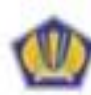

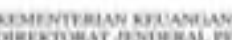

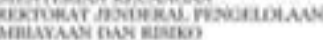

Clobal Sukuk kelima. penerbitan perdane Sukuk Wakala, $35 \%$ dialokaskan untuk invester islam dan Timur Tengah
Global Sukuk terbesar dan dual tranche Dertama

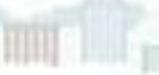

Source: (Finance., n.d.)

Indonesia is one of the issuers of sukuk in the world, the first issuance of sukuk in Indonesia in 2004, namely sukuk with an ijarah contract with a value of Rp. 4.7 trillion which continues to grow from year to year, here is the development of sukuk in Indonesia (Ardi, 2018):

Table 4. Development of Sukuk in Indonesia

\begin{tabular}{cl}
\hline Year & \multicolumn{1}{c}{ Sukuk } \\
\hline 2004 & The value of the sukuk with an ijarah contract with a value of Rp. 4.7 trillion \\
2005 & Issued by 3 companies that issue sukuk ijarah \\
2006 & Issued by 1 company to issue sukuk ijarah \\
2007 & Issued 3 sukuk ijarah and 1 sukuk with a mudharabah agreement \\
2008 & Issued 2 sukuk mudharabah, 4 sukuk ijarah, 2 SBSN \\
2009 & Issued 14 sukuk ijarah with 6 SBSNs \\
2010 & Issuing sukuk ijarah, mudharabah respectively 1. \\
2011 & Issued 1 sukuk mudharabah \\
2012 & The value of the sukuk ijarah is $\mathrm{Rp} .57 .09$ trillion \\
2014 & The increase in value in 2014 was 75.54 trillion \\
\hline
\end{tabular}

Source: (Ardi, 2018)

Since the issuance of state sharia securities (SBSN) for the first time in 2008 it has experienced a tremendous increase even in 2014 it experienced excess demand which in lowering the profit sharing that must be given to investors, sukuk in Indonesia is intended for development financing, government project financing can help the Indonesian economy besides sukuk as an alternative to halal investment for Muslims (Indriasari, 2018), sukuk as a new form of investment in Indonesia with a lot of interest from domestic investors which is marked by the value of sukuk which continues to increase from year to year. 
The purpose of issuing state sharia securities (SBSN) is to finance the state revenue and expenditure budget and to build government projects based on sharia principles using ijarah, mudharabah, musyarakah, istisna 'contracts issued directly by the government or through SBSN issuing companies in accordance with the provisions; has assets in the form of land and buildings (President of the Republic of Indonesia, 2008). The projects to be launched in the 2020 fiscal year are 728 projects spread across 34 provinces, as follows (Finance., n.d.):

1. A total of 30 transportation infrastructure projects at the Ministry of Transportation with a value of Rp.6.90 trillion;

2. A total of 171 road and bridge infrastructure projects at the Directorate General of Highways at the PUPR Ministry with a financing value of Rp.10.60 trillion;

3. A total of 66 infrastructure projects for flood and lahar control, management of dams and reservoirs, as well as management of main urban drainage at the Directorate General of Natural Resources at the Ministry of PUPR with a financing value of Rp.4.50 trillion;

4. A total of 10 haj embarkation projects and 40 integrated haj service center projects at the Directorate General of PHU of the Ministry of Religion, valued at Rp.460 billion;

5. A total of 6 constructions of PTKIN building facilities and facilities and 136 madrasas at the Directorate General of Islamic Education at the Ministry of Religion, valued at IDR 2.09 trillion;

6. A total of 228 construction and rehabilitation projects for marriage halls and Hajj rituals at the Directorate General of Islamic Community Guidance at the Ministry of Religion, valued at IDR 356.25 billion;

7. There are 6 conservation center development projects, 1 state forestry secondary school construction project and 2 laboratory construction at the Ministry of LHK worth IDR 237.41 billion;

8. A total of 24 higher education building construction projects at the Ministry of Research, Technology and Higher Education worth Rp1.49 trillion;

9. A total of 1 laboratory development project in BSN is worth IDR 70 billion;

10. A total of 4 laboratory development projects at LIPI worth IDR 500 billion; and

11. There is a total of 1 peseta component testing laboratory project at LAPAN valued at IDR 125 billion.

Sukuk must have clear underlying or assets, project-based sukuk are commonly used for developing countries with assets that can contribute $62 \%$ with the support of $19 \%$ of assets from global sukuk then based on the criteria for the return type of sukuk based on assets $98 \%$ from global suskuk with supporting assets. of $2 \%$ (Sillah, 2018). In the issuance of sukuk, there are several things that can affect it, such as company profits and then always adhering to sharia rules for the type of sukuk mudharabah issuance, other factors are the sukuk yield as well as the inflation rate and the age of the sukuk issuing company (Utami, Trinugroho, \& Sergi, 2019). 
Countries that issue sukuk will provide returns to the public as investors if the GDP (Gross Domestic Product) of a country is high which is marked by high tax revenues, the government can pay higher returns on the sukuk and vice versa, however, it must be noted that the quality of the sukuk issued is not only the quantity only takes into account the adaptation of the sukuk sharia law that is being traded (Hendri, 2018). Based on the estimation results from Distributed Lag (ARDL) in the long term that there is an exchange rate that has a significant effect on SBSN while inflation and interest rates do not have a significant effect on SBSN so that SBSN is a safe investment in accordance with sharia principles (Juaris, Masbar, \& Seftarita, 2018).

National sharia securities or SBSN in Indonesia are developing well as a financing instrument in helping the government revenue budget as well as a factor in the development of the Islamic financial industry, in the development of sukuk during 2008-2018 are as follows (Ministry of Finance, 2018).

1. State sukuk has experienced significant development according to data from the Ministry of Finance, the total accumulated sukuk issuance up to October 2018 was IDR 950 trillion or equivalent to USD 63 billion, outsatanding as of October 25 was IDR 657 trillion, so that the contribution of sukuk to APBN financing was $30 \%$ of the amount. tota of Government Securities (SBN) financing.

2. Sukuk financing is intended for project financing ( Project Financing Sukuk) such as financing infrastructure development; roads, bridges, dams, irrigation, groundwater management, national park development, schools and development, laboratory construction. This financing has been implemented from 2013 to 2018 in 34 provinces, which has reached IDR 62.4 trillion.

3. Since the issuance of regular sukuk in 2009, there has been tremendous development with the toral of retail sukuk issuance reaching Rp. 144.7 trillion which can be enjoyed by 243,364 domestic investors. Meanwhile, the development of savings sukuk that is favored by 11,338 investors has reached Rp. 2.6 trillion with an average of Rp. 228 million per investor.

4. Apart from retail sukuk, Indonesia also issued sovereign green sukuk in 2018 which was the first country in the world to issue this type of sukuk, besides that Indonesia is also the largest international sovereign sukuk issuer since 2009, this shows that Indonesia has shown support and contributed to the world. for the development of domestic and international Islamic finance.

5. Many achievements have been obtained by the state sukuk with various international awards such as;
a. Alpha Southeast Asia;
b. The Asset, Finance Asia;
c. Credit Magazine;
d. Asia Money;
e. IFR Asia;
f. Islamic Finance News;
g. Euromoney Islamic Finance Awards; 
h. Global Islamic Finance Awards;

i. Asia Pacific Green/SRI Bond Deal of the Year (Global Capital / Euromoney September 2018)

State sharia securities (SBSN) or sukuk are part of the issuance of sukuk in Indonesia, issued by the government with the aim of assisting the State Budget (APBN) in the form of government project financing, here are some developments from SBSN or sukuk in Indonesia:

\section{Islamic Fixed Rate (IFR)}

Islamic Fixed Rate or IFR is issued by the government with a term of more than 1 year through auction, private placement, closed secondary market, then investors will get a return every 6 months in rupiah currency (Ministry of Finance, 2016). Since 2008 and 2009 when it was published for the first time in the domestic market by means of bookbuilding (ordering for a certain period by way of auction) but after 2011 Islamic Fixed Rate (IFT) was no longer published then a series of Project Based Sukuk (PBS) was issued instead. with a system similar to that of IRT (Nopijantoro, 2018). There are several developments that occurred in the development of national securities, especially in the State Sharia Securities from 2014 to 2018 (Bank Indonesia, 2018) as follows:

Table 5 Position of Government Securities (SBN) in Billion Rupiah

\begin{tabular}{cccccccccc}
\hline $\begin{array}{c}\text { Type } \\
\text { of } \\
\text { SBSN }\end{array}$ & $\mathbf{2 0 1 4}$ & $\mathbf{2 0 1 5}$ & $\mathbf{2 0 1 6}$ & $\mathbf{2 0 1 7}$ & $\mathbf{2 0 1 8}$ & June & July & Agust & Sept \\
\hline $\begin{array}{c}\text { Fixed } \\
\text { Rate }\end{array}$ & 0 & 0 & 201,917 & 292,544 & 349,458 & 377,409 & 393,859 & 405,639 & 417,639 \\
$\begin{array}{c}\text { Retail } \\
\text { SBSN }\end{array}$ & 47,906 & 56,257 & 72,788 & 67,502 & 53,974 & 43,591 & 43,591 & 43,591 & 43,591 \\
$\begin{array}{c}\text { Sharia } \\
\text { SPN }\end{array}$ & 10,735 & 14,099 & 7,700 & 19,640 & 25,250 & 28,760 & 26,310 & 24,660 & 25,310 \\
$\begin{array}{c}\text { Savings } \\
\text { Sukuk } \\
\text { (ST) }\end{array}$ & 0 & 0 & 2,585 & 2,524 & 4,946 & 10,707 & 10,707 & 12,669 & 12,669 \\
\hline
\end{tabular}

Source: (Bank Indonesia, 2018)

\section{Retail Sukuk (SR)}

State Sharia Securities or SBSN issued by the government by means of bookbuilding, this series began to be issued in 2009 under the names SR-01 to SR-11 in 2019, where they can be traded with fixed yields. The issuance of this retail sukuk uses the Ijarah Sale and Lease Back contract using state-owned goods $(\mathrm{BMN})$ as the underlying, then the use of another contract is Ijarah Asset to be Leased using state-owned goods and projects ordered by the government as the underlying (Yaya \& Sofiyana, 2018). Following are some of the developments in retail sukuk in Indonesia.

Table 6 Types of Retail Sukuk and Their Development 


\begin{tabular}{|c|c|c|c|c|c|c|c|c|c|c|c|c|}
\hline$\stackrel{\mathscr{\Omega}}{\mathscr{\infty}}$ & $\begin{array}{l}\bar{\Xi} \\
\bar{Z} \\
\delta \\
\varnothing \\
0\end{array}$ & 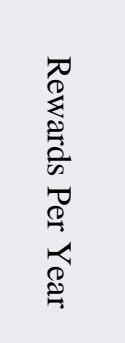 & 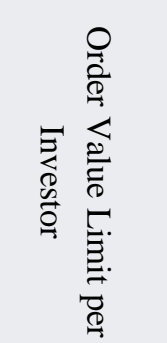 & $\begin{array}{l}\mathrm{Nu} \\
\mathrm{Ag} \\
\varpi \\
\mathscr{D}_{\pi}\end{array}$ & 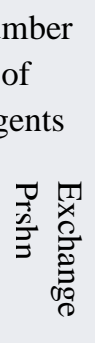 & $\begin{array}{l}\stackrel{0}{0} \\
\stackrel{0}{9} \\
\stackrel{0}{0} \\
\stackrel{0}{0} . \\
0\end{array}$ & $\begin{array}{l}\underset{0}{0} \\
\stackrel{0}{0} \\
< \\
0 \\
0 \\
0 \\
0 \\
0 \\
0 \\
0\end{array}$ & $\begin{array}{l}\varpi \\
\stackrel{0}{0} \\
0 \\
0 \\
\overrightarrow{0} \\
\overrightarrow{\tilde{w}} \\
\stackrel{0}{0}\end{array}$ & 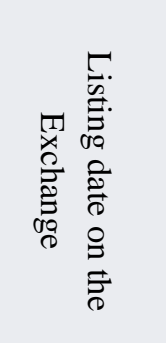 & 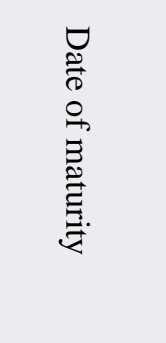 & 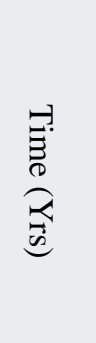 & \\
\hline $\begin{array}{l}\text { SR- } \\
002\end{array}$ & IDP000000705 & $8.70 \%$ & $\begin{array}{l}\text { A } \\
\text { multiple } \\
\text { of IDR } 5 \\
\text { million, } \\
\text { with no } \\
\text { maximum } \\
\text { limit }\end{array}$ & 10 & 8 & $\begin{array}{l}25 / 1-5 \\
/ 2-2010\end{array}$ & $8 / 2 / 2010$ & $10 / 2 / 2010$ & $\begin{array}{l}11 / \\
2 / 2010\end{array}$ & $10 / 2 / 2013$ & 3 yrs & $\begin{array}{l}\text { IDR } \\
8,033,8\end{array}$ \\
\hline $\begin{array}{l}\text { SR- } \\
003\end{array}$ & IDJ000004601 & $8.15 \%$ & $\begin{array}{l}\text { A } \\
\text { multiple } \\
\text { of IDR } 5 \\
\text { million, } \\
\text { with no } \\
\text { maximum } \\
\text { limit }\end{array}$ & 11 & 9 & $\begin{array}{l}7-18 / 2 \\
2011\end{array}$ & $\begin{array}{l}21 / 2 \\
2011\end{array}$ & $23 / 22011$ & $\begin{array}{l}24 / 2 \\
2011\end{array}$ & $\begin{array}{ll}23 & \text { Feb } \\
2014 & \end{array}$ & $\begin{array}{l}3 \\
\text { years }\end{array}$ & $\begin{array}{l}\text { IDR } \\
7,341,4\end{array}$ \\
\hline $\begin{array}{l}\text { SR- } \\
004\end{array}$ & IDJ000004809 & $6.25 \%$ & $\begin{array}{l}\text { A } \\
\text { multiple } \\
\text { of IDR } 5 \\
\text { million, a } \\
\text { maximum } \\
\text { of IDR } 5 \\
\text { billion }\end{array}$ & 13 & 11 & $\begin{array}{l}5-16 \\
\text { March } \\
2012\end{array}$ & $\begin{array}{l}19 \text { Mar } \\
2012\end{array}$ & $\begin{array}{l}\text { March 21, } \\
2012\end{array}$ & $\begin{array}{l}22 \text { March } \\
2012\end{array}$ & $\begin{array}{l}21 \text { Sept } \\
2015\end{array}$ & $\begin{array}{l}3.5 \\
\text { years }\end{array}$ & $\begin{array}{l}\text { IDR } \\
13,613\end{array}$ \\
\hline $\begin{array}{l}\text { SR- } \\
005\end{array}$ & IDJ000005509 & $6.00 \%$ & $\begin{array}{l}\text { A } \\
\text { multiple } \\
\text { of IDR } 5 \\
\text { million, a } \\
\text { maximum } \\
\text { of IDR } 5 \\
\text { billion }\end{array}$ & 16 & 9 & $\begin{array}{l}8-22 \\
\text { Feb } \\
2013\end{array}$ & $\begin{array}{l}25 \text { Feb } \\
2013\end{array}$ & $\begin{array}{l}27 \text { Feb } \\
2013\end{array}$ & $\begin{array}{l}28 \text { Feb } \\
2013\end{array}$ & $\begin{array}{l}27 \text { Feb } \\
2016\end{array}$ & 3 yrs & $\begin{array}{l}\text { IDR } \\
14,968\end{array}$ \\
\hline $\begin{array}{l}\text { SR- } \\
006\end{array}$ & IDJ000006200 & $8.75 \%$ & $\begin{array}{l}\text { A } \\
\text { multiple } \\
\text { of IDR } 5 \\
\text { million, a } \\
\text { maximum } \\
\text { of IDR } 5 \\
\text { billion }\end{array}$ & 19 & 9 & $\begin{array}{l}\text { Feb 14- } \\
28 \\
2014\end{array}$ & $\begin{array}{l}3 \text { Mar } \\
2014\end{array}$ & $\begin{array}{l}\text { March 5, } \\
2014\end{array}$ & $\begin{array}{l}\text { March 6, } \\
2014\end{array}$ & $\begin{array}{l}\text { March 5, } \\
2017\end{array}$ & 3 yrs & $\begin{array}{l}\text { IDR } \\
19,323\end{array}$ \\
\hline $\begin{array}{l}\text { SR- } \\
007\end{array}$ & IDJ000006705 & $8.25 \%$ & $\begin{array}{l}\text { A } \\
\text { multiple }\end{array}$ & 17 & 5 & $\begin{array}{l}23 \text { Feb- } \\
6 \text { March }\end{array}$ & $\begin{array}{l}9 \text { Mar } \\
2015\end{array}$ & $\begin{array}{l}\text { Wednesday, } \\
11 \quad \text { Mar }\end{array}$ & $\begin{array}{l}\text { Thursday, } \\
12 \text { Mar }\end{array}$ & $\begin{array}{l}\text { March } \\
11,2018\end{array}$ & $\begin{array}{l}3 \\
\text { years }\end{array}$ & $\begin{array}{l}\text { IDR } \\
21,965\end{array}$ \\
\hline
\end{tabular}


Dini Selasi

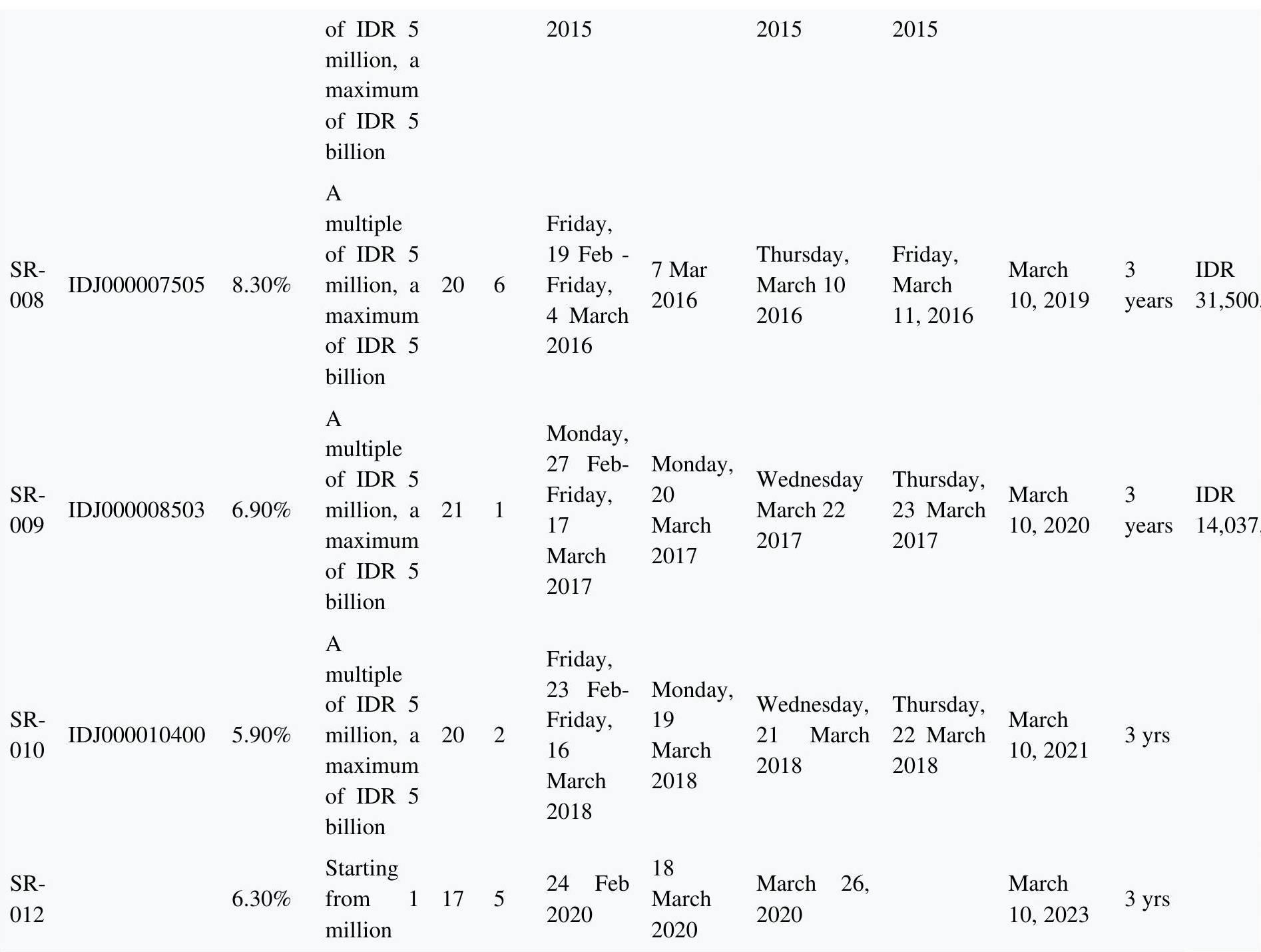

Source: http://kemenkeu.go.id/sukukritel

Retail sukuk in Indonesia are in great demand by the domestic community as an investment alternative, here are some projects that have been generated from retail sukuk financing (Ministry of Finance, 2020), namely:

1. The construction of Jalan Gerung Mataram, NTB, was financed by the State Sukuk for the Year 2015

2. Construction of the Amplas Medan Flyover Ramp on / off, financed by the State Sukuk for the 2016 fiscal year.

3. The construction of the IAIN Salatiga Central Java lecture building, funded by the State Sukuk for the 2015-2016 academic year.

4. Construction of the Solo - Ngawi toll road section I - Colomadu Karanganyar, Central Java, financed by the State Sukuk for the 2017-2018 academic year.

5. The construction of the UIN Manado North Sulawesi lecture building was funded by the State Sukuk for the 2018 year. 
6. The construction of the Cirebon-Kroya-Solo-Madiun-Jombang Java South Double Track Railway, was financed by the State Sukuk for the 2013-2019 fiscal year.

7. Construction of the New Yogyakarta International Airport (NYIA) underpass in Kulonprogo Regency, Yogyakarta Special Region (DIY). The cost required in the construction of this underpass is IDR 293 billion which will be put into operation on December 20, 2019.

8. Makassar Hajj hostel

9. Youtefa Bridge (Holtekamp) - Papua.

10. UIN Sunan Gunung Jati.

11. Musi 4 Bridge Palembang

12. Double-Doule Track of Manggarai Train - Cikarang

13. Notog Railway Tunnel - Banyumas

Retail sukuk issued by the Government also collaborates with distribution partners in Indonesia from the national banking sector as well as from various securities companies involved in the issuance of this sukuk (Government of the Republic of Indonesia, 2020) are as follows

1. PT Bank BRI Syariah, Tbk ;

2. PT Bank Central Asia, Tbk ;

3. PT Bank CIMB Niaga Tbk ;

4. PT Bank DBS Indonesia;

5. PT Bank HSBC Indonesia;

6. PT Bank Madiri (Persero), Tbk;

7. PT Bank Maubank Indonesia ;

8. PT Bank Muamalat Indonesia Tbk ;

9. PT Bank Negara Indonesia (Persero) Tbk;

10. PT Bank Panin Tbk ;

11. PT Bank Permata, Tbk ;

12. PT Bank Rakyat Indonesia (Persero) Tbk ;

13. PT Bank Syariah Mandiri .; PT Bank Tabungan Negara (Persero) Tbk :

14. PT Baeksa Investment Portal PT Danareksa Sekuritas.

15. PT Investree Rahika Jaya.

16. PT Mandiri Sekuritas.

17. PT Mitrausaha Indonesia Group.

18. PT Nusantara Sejahtera Investama.

19. PT Trimgah Sekuritas Indonesia,

20. PT Star Mercato Capitale.

21. PT Sinarmas Sekuritas.

22. PT Bank Danamon Indonesia, Tbk.

23. PT Bahana Sekuritas,

24. PT Bank Commonwealth.

25. PT Bank UOB Indonesia. 


\section{Global Sukuk or Indonesian State Sukuk (SNI)}

Issued by the government using the bookbuilding method in the form of foreign currency, namely USD issued in 2009 with a tradable nature and will get fixed returns. Based on research from Rahman (Rahman, Duasa, Kassim, \& Zainudin, 2017), sukuk published by the Government of Indonesia, Turkey, Malaysia, the United Arab Emirates, Bahrain using panel data from 2006 to 2013 show that only the inflation rate is able to influence the yield of the country's sukuk. Other factors that influence the development of sukuk are structural, financial and institutional factors, as well as the state's macroeconomic condition in the period 2001 to 2013 in 13 countries (Smaoui \& Khawaja, 2017). Sukuk financing by the government is mostly for infrastructure financing with procedures starting from project preparation, proposal, feasibility assessment, fiscal considerations, approval and rejection, allocation of funds, preparation for project implementation then funding for state sukuk, while the financing structure is divided into project financing and project underlying (Fauziah, Syifa, \& Nurwahidin, 2020).

When the global sukuk was first issued in 2009, it was already in demand by world investors and even experienced an excess of demand, the yields given were also much greater than that of the country sukuk issued domestically, the difference is approximately $3-5 \%$, this is one of the reasons factors of increasing demand for global sukuk, according to Eri Haryanto as an employee of the Directorate General of Financing and Risk Management of the Ministry of Finance of the Republic of Indonesia (Hariyanto, 2017) with the development of world investors, namely:

Table 7 Development of Indonesian State Sukuk Investors (SNI) SNI 25 series

\begin{tabular}{lll}
\hline \multicolumn{1}{c}{ Country } & total \\
\hline the middle East & $41 \%$ & \\
United States of America & $21 \%$ & \\
Europe & $16 \%$ & \\
Asia & $12 \%$ & \\
Indonesia & $10 \%$ & \\
\hline
\end{tabular}

Source: Ministry of Finance

Indonesia issued global sukuk with SNI21 and SNI26 series, according to the Directorate General of Financing and Risk Management that for the first time Indonesia issued global sukuk in dual-tranche (Risk, 2016) the issuance was carried out on March 21, 2016 and the settlement was carried out on March 29, 2016 which was listed on Singapore Stock Exchange and NASDAQ Dubai with the following conditions:

1. SNI21 series; 5-year tenor, will mature on March 29, 2021 with a yield of $3.4 \%$, with a nominal value of US $\$ 750$

2. SNI26 series; 10-year tenor, will mature on March 29, 2026 with a yield of $4.55 \%$ and a nominal value of US \$ 1.75 billion. 
3. Both of them use sharia principles with the wakalah contract also having underlying assets in the form of State Property; land and buildings by $51 \%$ and government projects by $49 \%$ which is the largest sukuk issuance in Asia.

In general, sukuk is in demand by world investors, especially for non-Muslim investors, this is because in Islam it focuses on openness or transparency so that no one is harmed, is careful not to carry out speculative activities, by sharing existing risks and the main thing. is not making investments that contain usury, there is a clear underlying condition and Indonesia is an international sovereign sukuk issuing country with a total of US \$ 16.15 billion (Directorate of Sharia Financing, 2018)

\section{Indonesian Hajj Fund Sukuk (ADHI);}

The contract used by ijarah al khadamat is non-tradable in nature which is a private placement which is a follow-up to the cooperation with the Ministry of Finance and the Ministry of Religion in 2009 in accordance with the DSN-MUI fatwa no.118 / DSN-MUI / 2009 with the underlying form of haj services (lodging, food and transportation). The Indonesian Hajj Fund Sukuk (SDHI) is very effective in financing because it can handle half of the service needs and costs of Indonesian Hajj which are marked by an increase in the quality of Hajj such as improvements to lodging or lodging, consumption and transportation used by Indonesian pilgrims (Sianipar, 2019). On November 4, 2015, the Directorate General of Risk and Financing Management of the Ministry of Finance issued state sharia securities with the SDHI 2023 A series (Directorate General of Financing and Risk Management, 2015) with several provisions, as follows:

1. Issued on November 4, 2015 and will mature on November 4, 2023.

2. Nominal value of Rp. 1,500,000,000,000.

3. Yield of $8.82 \%$ per annum, which is paid monthly (every 4th day).

4. Payment of the first yield on December 4, 2015 and payment of the last yield on November 4, 2023.

5. Trade terms; not tradable or non tradable.

6. Using Al Khadamat adad

7. Underlying; Services

8. Issuer; Indonesian SBSN issuing company.

In 2018 the Indonesian hajj fund sukuk or SDHI has reached 36.70 trillion, using the Ijarah al khadamat agreement with the underlying Hajj services with the issuer of the Indonesian SBSN issuing company, SDHI has issued its sukuk since 2011 with various series as delivered in the 7 th IndonesiaX seminar Educational Conference: "Islamic Economics and Finance: Present and Future" (Directorate of Sharia Financing, 2018) :

Table 8 SDHI Outstanding as of February 2018

\begin{tabular}{cccccc}
\hline No. & Series & Publishing & Due date & Rewards & Amount (Rp) \\
\hline 1. & SDHI 2021A & 11-Apr-11 & 11-Apr-21 & $8.00 \%$ & $2,000,000,000,000$ \\
2. & SDHI 2021B & 17-Oct-11 & 17-Oct-21 & $7.16 \%$ & $3,000,000,000,000$
\end{tabular}




\begin{tabular}{ccclll} 
3. & SDHI 2020E & 21-Mar-17 & 21-Mar-20 & $7.14 \%$ & $2,000,000,000,000$ \\
4. & SDHI 2019A & 21-Mar-12 & 21-Mar-19 & $5.46 \%$ & $3,000,000,000,000$ \\
5. & SDHI 2022A & 21-Mar-12 & 21-Mar-22 & $5.91 \%$ & $3,342,000,000,000$ \\
6. & SDHI 2020A & 27-Apr-12 & 27-Apr-20 & $5.79 \%$ & $1,500,000,000,000$ \\
7. & SDHI 2018A & 30-May-12 & 30-May-18 & $6.06 \%$ & $2,500,000,000,000$ \\
8. & SDHI 2020B & 28-Jun-12 & 28-Jun-20 & $6.20 \%$ & $1,000,000,000,000$ \\
9. & SDHI 2020C & 3-Jan-14 & 3-Jan-20 & $8.30 \%$ & $3,000,000,000,000$ \\
10. & SDHI 2019B & 11-Feb-14 & 11-Feb-19 & $8.05 \%$ & $2,000,000,000,000$ \\
11. & SDHI 2022B & 11-Feb-14 & 11-Feb-22 & $8.75 \%$ & $2,000,000,000,000$ \\
12. & SDHI 2024A & 11-Feb-14 & 11-Feb-24 & $9.04 \%$ & $2,000,000,000,000$ \\
13. & SDHI 2024A & 25-Mar-14 & 25-Mar-29 & $8.43 \%$ & $1,000,000,000,000$ \\
14. & SDHI 2029B & 13-Aug-14 & 13-Aug-29 & $8.62 \%$ & $2,855,000,000,000$ \\
15. & SDHI 2020D & 29-Jun-15 & 29-Jun-20 & $8.20 \%$ & $1,000,000,000,000$ \\
16. & SDHI 2025A & 8-Jul-15 & 8-Jul-25 & $8.30 \%$ & $2,000,000,000,000$ \\
17. & SDHI 2023A & 4-Nov-15 & 4-Nov-23 & $8.82 \%$ & $1,500,000,000,000$ \\
18. & SDHI 2019C & 27-Apr-16 & 27-Apr-19 & $7.20 \%$ & $1,000,000,000,000$ \\
Total Indonesian Hajj Fund Sukuk (SDHI) & & & $36,697,000,000,000$ \\
\hline
\end{tabular}

\section{Sharia State Treasury Bills (SPNS)}

Is a short-term sukuk (tenor 6 months) with the aim of assisting the management of the state treasury and the development of the Islamic money market. Sharia State Treasury Bills (SPNS) are state sukuk that are traded through auctions and private placements using the rupiah currency with a term or tenor of 1 year with a discount in the form of a discount (Djppr, 2019). In fact, the government sharia bonds or sukuk as a whole have a lower risk and better performance than conventional state bonds, the focus of the instruments studied from 2008 to 2016, such as the average interest rate of Bank Indonesia, yield to maturity, current yield, global bond rating (Ulumuddin, 2016).

The state sukuk with the SPNS series (Sharia State Treasury Bills) has conducted an auction on April 7, 2020 in an effort to meet the 2020 APBN budgeting target, the auction will be announced on the same day where the auction is regulated in the Minister of Finance regulation number 05 / PMK.08 / 2012 concerning the Issuance and Sale of State Sharia Securities in the Domestic Primary Market by Auction Method as amended by Regulation of the Minister of Finance Number 20 / PMK.08 / 2017, the contract used in SPNS sukuk trading uses the Ijarah Sale and Lease Back agreement based on fatwas National Sharia Council - Indonesian Ulema Council (DSN-MUI) number 72 / DSN-MUI / VI / 2008 (DSNMUI, 2008). The following are the terms and conditions of the SPNS (Djppr, 2019).

Table 9 Term and Condition of Sharia State Treasury Bills (SPNS)

\begin{tabular}{lll}
\hline Term and Condition & \multicolumn{1}{c}{$\begin{array}{c}\text { SPN-S 08102020 } \\
\text { (new issuance) }\end{array}$} & \multicolumn{1}{c}{$\begin{array}{c}\text { SPN-S 08012021 } \\
\text { (new issuance) }\end{array}$} \\
\hline $\begin{array}{l}\text { Due date } \\
\text { Rewards }\end{array}$ & $\begin{array}{l}\text { 8 October 2020 } \\
\text { Discount }\end{array}$ & $\begin{array}{l}\text { January 8, 2021 } \\
\text { Discount }\end{array}$ \\
Underlying Asset & $\begin{array}{l}\text { Projects / Activities in the 2020 State } \\
\text { Budget and State Property }\end{array}$ & $\begin{array}{l}\text { Projects / Activities in the 2020 State } \\
\text { Budget and State Property }\end{array}$ \\
Auction Date & 7 April 2020 & 7 April 2020
\end{tabular}


Settlement Date

Non-competitive Purchase Allocation Indicative Targets Bidders
April 9, 2020

$50 \%$ of the amount won

IDR 7,000,000,000,000.00

Bank: (1) PT. Bank Mandiri (Persero), Tbk (2) PT. Bank Rakyat Indonesia (Persero), Tbk (3) PT. Bank Negara Indonesia (Persero), Tbk (4) PT. Bank Permata, Tbk (5) PT. Bank Panin, Tbk (6) PT. Bank HSBC Indonesia (7) PT. Bank OCBC NISP, Tbk (8) Standard Chartered Bank (9) PT. Bank CIMB Niaga, Tbk (10) PT. Bank Maybank Indonesia, Tbk (11) Citibank NA (12) PT. Bank Negara Indonesia Syariah (13) PT. Bank Central Asia, Tbk (14) Deutsche Bank AG (15) PT. Bank BNP Paribas Indonesia (16) PT. Bank Syariah Mandiri (17) PT. Bank BRISyariah, Tbk

Securities $\quad$ Companies:
PT. Danareksa $\quad$ Sekuritas
PT. Mandiri Sekuritas (3) PT. Trimegah
Sekuritas Indonesia, Tbk
PT. Bahana Securities
April 9, 2020

$30 \%$ of the amount won

IDR 7,000,000,000,000.00

Bank: (1) PT. Bank Mandiri (Persero), Tbk (2) PT. Bank Rakyat Indonesia (Persero), Tbk (3) PT. Bank Negara Indonesia (Persero), Tbk (4) PT. Bank Permata, Tbk (5) PT. Bank Panin, Tbk (6) PT. Bank HSBC Indonesia (7) PT. Bank OCBC NISP, Tbk (8) Standard Chartered Bank (9) PT. Bank CIMB Niaga, Tbk (10) PT. Bank Maybank Indonesia, Tbk (11) Citibank NA (12) PT. Bank Negara Indonesia Syariah (13) PT. Bank Central Asia, Tbk (14) Deutsche Bank AG (15) PT. Bank BNP Paribas Indonesia (16) PT. Bank Syariah Mandiri (17) PT. Bank BRISyariah, Tbk

1) Securities Companies:

(2) PT. Danareksa Sekuritas PT. Mandiri Sekuritas

(4) PT. Trimegah Sekuritas Indonesia, Tbk (4) PT. Bahana Securities

Source: Directorate of Sharia Financing, Ministry of Finance

\section{Project Based Sukuk (PBS)}

Published in 2011 with medium to long tenor with fixed yield aimed at institutional investors through domestic primary market auction. The same is the case with the State Sharia Treasury (SPSN), Project Based Sukuk (PBS) where the auction is simultaneously carried out with SPSN where PBS uses the Ijarah Asset to be Leased agreement based on the DSN-MUI fatwa number 76 / DSN -MUI / VI / 2010 (DSN-MUI, 2010). Following are the terms and conditions of the Project Based Sukuk (PBS) which aims to finance the 2020 State Budget, the auction is conducted openly which can submit bids at auction but purchases through auction participants who have received approval from the Ministry of Finance of the Republic of Indonesia (djppr, 2020).

Table 10 Term and Condition Project Based Sukuk (PBS)

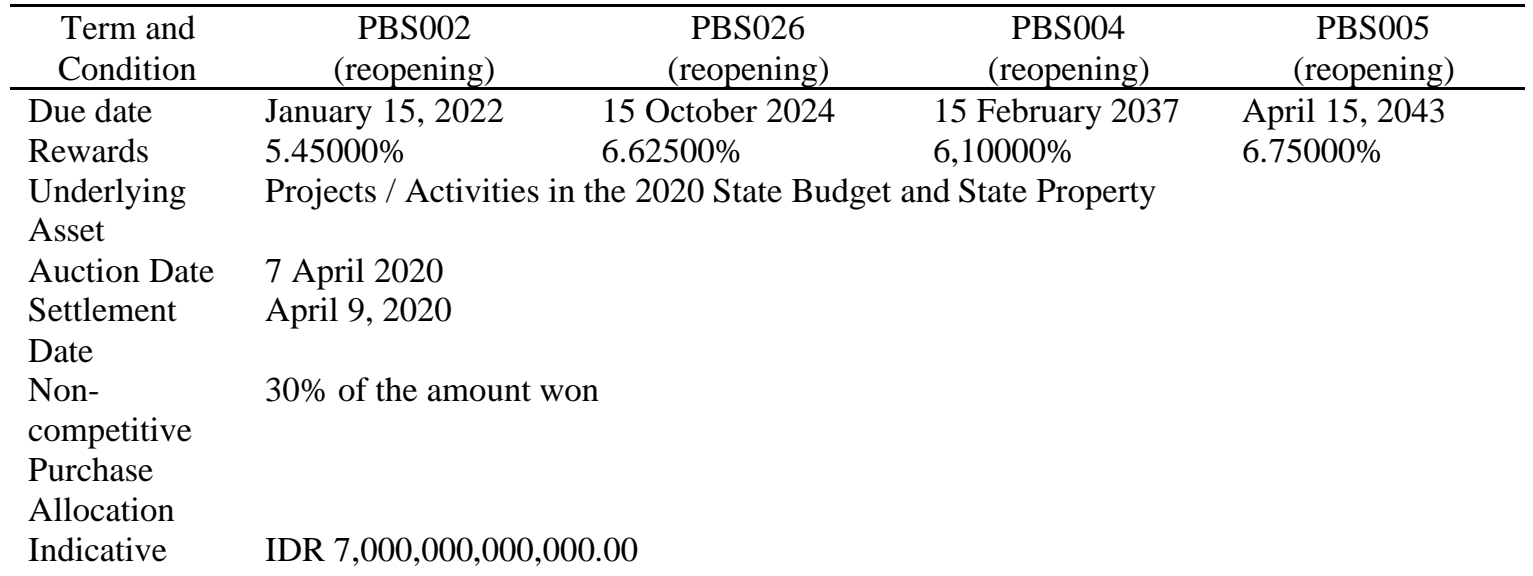


Bidders Bank: (1) PT. Bank Mandiri (Persero), Tbk (2) PT. Bank Rakyat Indonesia (Persero), Tbk (3) PT. Bank Negara Indonesia (Persero), Tbk (4) PT. Bank Permata, Tbk (5) PT. Bank Panin, Tbk (6) PT. Bank HSBC Indonesia (7) PT. Bank OCBC NISP, Tbk (8) Standard Chartered Bank (9) PT. Bank CIMB Niaga, Tbk (10) PT. Bank Maybank Indonesia, Tbk (11) Citibank NA (12) PT. Bank Negara Indonesia Syariah (13) PT. Bank Central Asia, Tbk (14) Deutsche Bank AG (15) PT. Bank BNP Paribas Indonesia (16) PT. Bank Syariah Mandiri (17) PT. Bank BRISyariah, Tbk

Securities Companies : (1) PT. Danareksa Sekuritas (2) PT. Mandiri Sekuritas (3) PT. Trimegah Sekuritas Indonesia, Tbk (4) PT. Bahana Securities

Source: Directorate of Sharia Financing, Ministry of Finance

\section{Savings Sukuk (ST)}

Issued in 2016 as part of the retail rate, aimed at domestic investors with a minimum purchase of 2 million, using a fixed yield system that is paid every month (tenor 2 years). Savings sukuk with series ST-001 on 22 August - 2 September 2016 with a 2-year tenor with a yield of $6.9 \%$ per year that cannot be traded on the secondary market (non-tradable), this savings sukuk aims to finance the state budget (djppr) (Ministry of Finance, 2018). Savings sukuk have almost the same objectives in broad outline for the types of State Sharia Securities or SBSN, namely to help finance the state budget by building infrastructure development, education, health and also helping the government in limiting the arrival of foreign investors (Hastuti, 2018).

\section{Green Sukuk (GT)}

The issuance of sukuk in all series issued by the government has the same objectives, namely to help finance the state budget and government projects, according to Suherman (Suherman, 2019) in his research that green bonds are the development of green sukuk in the country and show a positive increase until 2029, the number of enthusiasts from domestic investors towards this type of sukuk besides that demand from foreign investors is also very good for the state sukuk market. The following is the development of green sukuk for the year based on the green sukuk report in March 2020 where the Government of Indonesia has issued green sukuk during the period February 2018 and 2019 with the number of the Indonesian Government having issued two global sovereign green sukuk Twice in a row in 2018 amounting to US \$ 1, 25 billion and US \$ 750 million with a total amount of US $\$ 2$ billion, here are the developments of green sukuk in Indonesia (Ministry of Finance, 2020).

1. Each issue is divided into $49 \%$ new project financing while $51 \%$ for existing project financing, the results are allocated to several sectors which are a collaboration between the Ministry of Transportation, the Ministry of Energy and Mineral Resources and the Ministry of Work and Housing, namely;

a. For renewable energy.

b. Climate change resilience for areas that are highly vulnerable or at risk of disasters.

c. Energy efficiency.

d. Waste management and waste into energy. 
e. Sustainable transportation.

2. Allocation by sector

Table 11 Allocation by Sector for Green Sukuk

\begin{tabular}{lll}
\hline \multicolumn{1}{c}{ Sector } & \multicolumn{1}{c}{2018} & \multicolumn{1}{c}{2019} \\
\hline $\begin{array}{l}\text { For renewable energy } \\
\text { Climate change resilience for areas that } \\
\text { are highly vulnerable or at risk of } \\
\text { disasters }\end{array}$ & $102,519,477(8 \%)$ & $41,262,073(5 \%)$ \\
$\begin{array}{l}\text { Energy efficiency } \\
\text { Waste management and waste into }\end{array}$ & $73,818,308(17 \%)$ & $80,217,156(11 \%)$ \\
energy & $92,598,526(7 \%)$ & $69,492,775(9 \%)$ \\
Sustainable transportation. & $772,805,236(62 \%)$ & $360,480,724(48 \%)$
\end{tabular}

3. Allocation based on activity

In 2018 adaptation was $17 \%$ and mitigation was 83\%, while in 2019 adaptation was $11 \%$ and mitigation was $89 \%$.

4. Geographical spread of the 2019 green sukuk project

Table 12 Distribution of 2019 green sukuk project locations

\begin{tabular}{|c|c|}
\hline Sector & Location \\
\hline For renewable energy & $\begin{array}{l}\text { Papua, West Papua, East Nusa Tenggara, North Sulawesi, } \\
\text { Sulawesi, North Sulawesi, Southeast Sulawesi, South } \\
\text { Kalimantan, North Kalimantan, East Kalimantan, West } \\
\text { Sumatra, Riau, Gorontalo, West Kalimantan, } \\
\text { North Sumatra, Central Java, West Java, Maluku, West } \\
\text { Nusa Tenggara }\end{array}$ \\
\hline $\begin{array}{l}\text { Climate change resilience for areas } \\
\text { that are highly vulnerable or at } \\
\text { risk of disasters }\end{array}$ & $\begin{array}{l}\text { West Java, Central Java, Yogyakarta, North Sumatra, West } \\
\text { Sumatra, North Sulawesi, Maluku, Bali }\end{array}$ \\
\hline Energy efficiency & $\begin{array}{l}\text { Jakarta, Central Java, East Java, Aceh, North Sumatra, } \\
\text { West Sumatra, Riau, South Sumatra, West Kalimantan, } \\
\text { South Kalimantan, West Kalimantan, North Kalimantan, } \\
\text { North Sulawesi, South Sulawesi, Southeast Sulawesi, } \\
\text { Maluku, Bali, East Nusa Tenggara Timur, Papua, West } \\
\text { Papua, West Java }\end{array}$ \\
\hline $\begin{array}{l}\text { Waste management and waste into } \\
\text { energy }\end{array}$ & All Provinces except East Kalimantan \\
\hline Sustainable transportation. & $\begin{array}{l}\text { North Sumatra, West Sumatra, North Sumatra, Jakarta, } \\
\text { West Java, Central Java, East Java }\end{array}$ \\
\hline
\end{tabular}

\section{Conclusion}

The state sharia securities or SBSN issued by the Government of Indonesia have gone through a very long journey starting from 2004. Domestic investors are more familiar with the term sukuk, the purpose of issuing various series of sukuk is to help finance the APBN through various government projects. SBSN or sukuk with various series including Islamic Fixed Rate (IFR) sukuk, retail sukuk, green sukuk, savings sukuk, Indonesian hajj fund sukuk (SDHI), Project Based Sukuk (PBS), Sharia State 
Dini Selasi

Treasury (SPNS). Sukuk financing is allocated mostly for government projects throughout Indonesia, so it is clear that the dominance of its financing is allocated for infrastructure activities such as building roads, bridges, hospitals, educational facilities at various levels.

\section{REFERENCES}

Aminy, Muhammad Habibullah. (2018). Development Of Sharia Bond (Sukuk) In Indonesia. Iqtishaduna. 9 (2), 135-147.

Ardi, Muhammad. (2018). The Effect of Sukuk on Indonesia's Economic Growth. Iqtishaduna. 9 (1), 36-46.

Bank Indonesia. (2018). Position Of State Securities (SBN). Retrieved July 4, 2020, from bi.go.id. Retrieved from website: https://www.bi.go.id/seki/tabel/TABEL4_4.pdf

Creswell, John W., \& Clark, Vicki L. Plano. (2017). Designing and conducting mixed methods research. Sage publications.

Directorate General of Financing and Risk Management. (2015). Issuance of State Sharia Securities Series SDHI 2023 A through the Placement of Haii Funds. Retrieved August 7, 2020, from the Ministry of Finance. Retrieved from website: https://www.djppr.kemenkeu.go.id/uploads/files/dmodata/in/9Berita/SBSN/2015/S P_SDHI 2023A (IND) .pdf

Directorate of Sharia Financing. (2018). State Sukuk and National Development Financing. Retrieved August 7, 2020, from 7 th IndonesiaX Educational Conference: "Islamic Economics and Finance: Present and Future." Retrieved from website: https://seminar.indonesiax.co.id/files/07/suminto.pdf?raw=true

DJPPR. (2020). Planned Auction of State Sharia Securities or State Sukuk on April 7 , 2020. Retrieved August 7, 2020,.

Djppr. (2019). Sharia State Treasury Bills (SPNS). Retrieved from kemenkeu.go.id. Retrieved from website: https://www.djppr.kemenkeu.go.id/\#/id/page/produk 
DSN-MUI. (2019). DSNMUI No.80 / DSNMUI / III / 2011. Retrieved March 10, 2019, from DSN-MUI. Retrieved from website: https://dsnmui.or.id/category/fatwa/page/5/

DSN-MUI. (2008). fatwa of the National Sharia Council - Indonesian Ulema Council (DSN-MUI) number 72 / DSN-MUI / VI / 2008.

DSN-MUI. (2010). DSN-MUI Fatwa number 76 / DSN-MUI / VI / 2010 concerning Project Based Sukuk (PBS). , dsnmui.or.id § (2010).

Fauziah, Syifa, \& Nurwahidin, Nurwahidin. (2020). Infrastructure Financing with Sukuk Negara in Indonesia: Procedure and Structure. MEA Scientific Journal (Management, Economics, \& Accounting), 4 (1), 30-42.

Finance., Ministry of. (n.d.). State Sharia Securities. Retrieved July 15, 2020. Retrieved from website: https://www.djppr.kemenkeu.go.id/page/load/1656

Hariyanto, Eri. (2015). Reputation of Indonesia's Global Sukuk. Directorate General of Finance and Risk Management, Ministry of Finance of the Republic of Indonesia .

Hariyanto, Eri. (2017). The Strategic Role of State Sukuk. Retrieved July 16, 2020, from the Directorate of Sharia Financing, DJPPR, Ministry of Finance website: Retrieved from https://www.djppr.kemenkeu.go.id/page/load/1770

Hastuti, Erma Sri. (2018). Savings Sukuk: Sharia Investment Supports Inclusive Economic Development. Journal of Jurisprudence, 7 (2), 114-122. Retrieved from

Hendri, Zul. (2018). Can Sukuk Become a Primadonna In Indonesia? Judging From The Development of Sukuk In Several Countries. IQTISHADUNA: Jurnal Ilmiah Ekonomi Kita, 7(2), 168-179.

Hidayat, Taufik. (2011). Smart Book of Sharia Investments (1st ed.). Retrieved from ((1st ed.)). Retrieved from https://books.google.co.id/books?hl=en\&lr=\&id=2nPqgz2eJRoC\&oi=fnd\&pg=PR $3 \& d q=I n v e s t m e n t+i n+$ Islam $\&$ ots $=655 \mathrm{FBa} 1 \mathrm{Nag} \&$ sig $=$ QV7DZe3QqEv $=$ NAVxKmt $4 \mathrm{~V} \&$ investment

IDX Islamic. (n.d.). Sharia Products. Retrieved November 15, 2018, . Retrieved from website: http://www.idx.co.id/idx-syariah/produk-syariah

Indriasari, Ika. (2018). Analysis of Selection of Sukuk as an Investment Instrument. Stability: Journal of Management and Business, 1 (1).

Juaris, Juaris, Masbar, Raja, \& Seftarita, Chenny. (2018). Analysis of The Effect of Monetary Policy on Government Sharia Securities (SBSN) in Indonesia. Sriwijaya International Journal of Dynamic Economics and Business, 2(2), 109-122.

Ministry of Finance. (2016). State Sharia Securities. Retrieved July 15, 2020, from 
Djppr.kemenkeu.go.id.

Retrieved

from

website: https://www.djppr.kemenkeu.go.id/page/load/1656

Ministry of Finance. (2018). It has been a decade of State Sukuk Contribution to the Benefit of the Nation.

Ministry of Finance. (2020). Retail Sukuk Project \# InvestasiRakyatPenuhMan Benefits. Retrieved July 4, 2020, .

Ministry of Religion of the Republic of Indonesia. (2015). Al-Qur'an and its Translation. Semarang: Semarang: PT.Kumudasmoro Grafindo.

Nopijantoro, Wurjanto. (2018). Surat Berharga Syariah Negara Project Based Sukuk (SBSN PBS): sebuah Instrumen Alternatif Partisipasi Publik dalam Pembiayaan Infrastruktur. Substansi, 1(2), 390-406.

President of the Republic of Indonesia. (2008). UU no. 19 of 2008 concerning SBSN.

Rahman, Maya Puspa Binti, Duasa, Jarita, Kassim, Salina, \& Zainudin, Wan Rahini Aznie. (2017). Sovereign Sukuk Pricing Analysis: Do Macroeconomic Variables Matter? International Journal of Economics, Management and Accounting, 25(3), 513-528.

Risk, Directorate General of Financing Management and. (2016). For the First Time, the Government Issued Global Dual-Tranche Sukuk. Retrieved August 6, 2019, from the Ministry of Finance's website: $h$. Retrieved from ttps://www.kemenkeu.go.id/publikasi/berita/pertama-kalinya-pemerintah-terbitensukuk-global-dual-tranche/

Sianipar, Ibn SYifa Al Habib. (2019). Analysis of Hajj Fund Management in Indonesian Hajj Sukuk Funds . North Sumatra State Islamic University.

Sillah, Bukhari M. S. (2018). Project-backed sukuk: Can it be a model for resource mobilization, risk sharing and capital market development in developing economies. Journal of Islamic Banking \& Finance, 35(1), 68-83.

Smaoui, Houcem, \& Khawaja, Mohsin. (2017). The determinants of Sukuk market development. Emerging Markets Finance and Trade, 53(7), 1501-1518.

Suherman, Suherman. (2019). Identification of the Green Sukuk Market Potential of the Republic of Indonesia. Human Falah: Journal of Islamic Economics and Business, $1(6)$.

Ulumuddin, S. Y. (2016). Analisis Perbandingan Kinerja Obligasi Syariah Negara Dengan Obligasi Konvensional Negara Pada Periode 2008-2016 (Survey Pada Sukuk Ritel Indonesia, Surat Berharga Syariah Negara, Surat Perbendaharaan Negara, Obligasi Ritel Indonesia, dan Obligasi Negara Republik Indonesia). Universitas Widyatama. 
Utami, Datien Eriska, Trinugroho, Irwan, \& Sergi, Bruno S. (2019). What Determines Sukuk Issuance Type in Indonesia?', Asia-Pacific Contemporary Finance and Development (International Symposia in Economic Theory and Econometrics, Volume 26). Emerald Publishing Limited.

Yaya, Rizal, \& Sofiyana, Ekta. (2018). Pengaruh Sukuk Ritel Pemerintah Terhadap Penghimpunan Dana Pihak Ketiga Bank Syariah. Media Riset Akuntansi, Auditing \& Informasi, 18(2), 153-168. 